\title{
The Ecological Status of Lakes in National and Landscape Parks: Does the Location of a Lake and Its Catchment within a Protected Area Matter?
}

\author{
Agnieszka Pasztaleniec*, Sebastian Kutyla \\ Department of Freshwater Assessment Methods and Monitoring, \\ Institute of Environmental Protection - National Research Institute, \\ Kolektorska 4, 01-692 Warsaw, Poland \\ Received: 24 January 2014 \\ Accepted: 9 May 2014
}

\begin{abstract}
This study identifies the ecological status of lakes which are significant water bodies located within Polish national and landscape parks. The assessment carried out on the basis of data from the National Environmental Monitoring System coming from 2010-12 took into account the requirements of the Water Framework Directive (WFD). Half of the lakes analyzed were characterized by at least good status, while the others were in moderate or even poor or bad status, although they were situated in protected areas. The study shows multi-aspect (morphometric, hydrological, and catchment-related) factors that determine the water quality and the status of the lake ecosystem. A strong correlation was found between eutrophication indicators (chlorophyll $a$ concentration, water transparency, nutrient concentrations in water) and the majority of limnological parameters of lakes. There was no direct relationship between the percentage shares of the major land uses of lake catchments and the ecological status of lakes, but the nitrogen and phosphorus load theoretically emerging in the catchment correlated with the nutrient concentrations in water, as well as with chlorophyll $a$ and water transparency. On the basis of data available, it proved impossible to identify a positive impact of covering lakes with protection within a national or landscape park on their ecological status.
\end{abstract}

Keywords: lakes, lake catchments, ecological status, national and landscape parks, environmental monitoring

\section{Introduction}

The quality of lake waters is affected by a number of factors that have a natural character or ensue from human activities. Anthropogenic impacts result usually in a deterioration of the natural values of an aqueous system as a whole; however, intervention is easier in the case of humancaused changes, since they can be eliminated completely or

*e-mail: paszta@ios.edu.pl at least reduced, or their impacts can be mitigated. Different forms of natural protection are designed to serve this purpose. Among them, large-area national and landscape parks, enabling the control of external influences, are of the greatest importance for lake ecosystems. A national park (NP) is a form of nature protection involving the highest protection requirements in Poland [1]. A landscape park (LP) is a form with a more lenient protection regime, allowing for the economic development of its area, but one which would ensure the preservation of the natural values of a park [2]. 
Given the existing legal restrictions, ensuring or restoring at least good ecological status of lakes in protected areas should be less problematic than in the case of lakes situated outside of protected areas.

By 2014, 23 national parks and 121 landscape parks had been established in Poland. The oldest landscape parks were set up in the second half of the 1970s, and the youngest one in 2001. The provisions of the conservation plans of parks list objectives related to the protection of aqueous ecosystems, such as:

- Improving the resilience of surface water ecosystems to degradation

- Reducing nutrient runoffs from the fields into surface waters

- Maintaining the high quality and properties of the physicochemical composition of water

- Counteracting the growth of trophy of surface waters

- Creating buffer zones around water courses and water bodies, etc.

In Poland, intense eutrophication is the main factor which poses a risk for the water quality in Polish lakes [3]. It is understood as an effect of human activities that lead to higher nutrient concentrations in water and a number of the related adverse processes that cause a gradual degradation of an ecosystem [4]. In protected areas, where generally there are no significant point sources of pollution, the surface runoff is a major source of nutrients [5]. Therefore, knowledge of the transport of biogenic elements is particularly important for understanding the functioning of aquatic ecosystems in protected areas. The amount of nitrogen and phosphorus loads transferred from the catchment to surface waters depends on various factors such as the hydrological regime, land use, and amount of fertilization. Moreover, morphological and physical-limnological properties of a lake determine its susceptibility to external influences exerted on them; therefore, they were taken into account in water quality assessment systems $[6,7]$. In the ecological status assessment, the abiotic type of lake is taken into account, according to the requirements of the Water Framework Directive (WFD) [8, 9]. A number of studies [e.g. 10-14] have presented the significance of the catchment area properties for surface runoffs of nutrients and toxic substances and, hence, for the quality of lake waters. They have confirmed that a lake, along with its catchment, constitutes a dynamic ecological system and that the risk of lake eutrophication is higher when the catchment areas are dominated by farmland and urbanized areas. There are publications discussing issues concerning the water quality of Polish lakes in protected areas against the background of land use. Studies conducted within Wielkopolski National Park by Szyper and Gołdyn [15] indicate the great importance of diffuse sources that supply varied loads of nitrogen and phosphorus to lakes, depending on the catchment use and type of lake. In Wielkopolski NP, significant loads of nutrients came from arable fields, meadows, and pastures areas, along with their inflow with the rivers, while point sources of pollution were much less significant [15]. Long-term studies on accelerated fertilization of lakes were undertaken in the Masurian LP, Suwalski
LP, and Wigierski NP $[5,16,17,18,19,20]$. The northeastern part of Poland is characterized by less intensive farming than its western part. In addition, the decline of fertilizer use in the 1990s, the development of wastewater treatment plants, and a lack of strongly urbanized areas and large industrial plants contributed to the slowing down of the eutrophication processes $[3,21,22]$. Nevertheless, as underlined by Siuda et al. [22], the situation of inhibited eutrophication or even de-eutrophication of lakes is temporary and in the future increased imports of nutrients from catchments are expected as a consequence of growing tourism and a high share of monocultural agriculture. Thus, eutrophication is still the main threat for waters in Masurian LP and Wigierski NP. The role of external sources in eutrophication of water bodies located in the Drawieński NP was identified by Szyper and Kraska [23]. These authors considered that the fundamental cause of eutrophication of closed lakes were surface runoffs, while flowthrough lakes were, first of all, supplied by phosphorus and nitrogen loads reaching them with the river inflow. A wide range of the nutrient loading by catchments and the contributing dispersed factors (angling and recreational activities), as well as the natural susceptibility of a lake to degradation are reflected in the differentiated trophic conditions of lakes in protected areas [5, 12, 13, 15, 18, 21-24].

An important issue that has not yet been explored to a great extent is how restrictions on the management of the areas of national and landscape parks affect the quality of waters situated within their boundaries and the degree to which this quality relates to the size of a catchment protected under these forms of natural protection. The subject matter of the study is the presentation of the ecological status of lakes situated within national and landscape parks and the examination of the relationship between the quality of their waters and the land use of the catchment area, taking into account the size of the area covered by protection. In other words, an attempt was made to answer the question whether it is a general rule that parks protect (ensure) the maintenance of good ecological status of lakes or whether covering a lake and its catchment with protection has a positive impact on the quality of their waters.

\section{Methods}

Spatial and statistical analyses were carried out using the environmental database on Polish lakes, "JEZIORA [LAKES] 2," developed at the Department of Freshwater Assessment Methods and Monitoring of the Institute of Environmental Protection - National Research Institute (IEP-NRI). The database collects data from the National Environmental Monitoring System (NEMS) concerning lake water quality, provided by the Chief Inspectorate for Environmental Protection (CIEP). Moreover, it contains information on the morphometry of lakes and their geographical locations. The two modules applied in the database - a tabular one (elaborated upon using MS Access 2007 software) and a graphic one (developed using ArcGIS 10.1 software), enable a search for a relationship between 
Table 1. The values of unit loads of nutrients depend on type of land use (according to [28]).

\begin{tabular}{|l|c|c|}
\hline \multicolumn{1}{|c|}{ Type of land use } & \multicolumn{2}{c|}{ Unit loads (kg/ha/year) } \\
\cline { 2 - 3 } & $\mathrm{N}$ & $\mathrm{P}$ \\
\hline Forests & 1.5 & 0.1 \\
\hline Agricultural areas and discontinuous urban fabric: & 9.0 & 0.3 \\
\hline in 11 provinces with lower pressure* & 12.0 & 0.4 \\
\hline in 5 provinces with higher fertilization and soil nutrients availability** & 3.0 & 0.2 \\
\hline Pastures: & 4.5 & 0.3 \\
\hline \multicolumn{1}{|c|}{ in 11 provinces with lower pressure* } & 1.5 & 0.1 \\
\hline Wetlands & 3.0 & 0.2 \\
\hline Land principally occupied by agriculture with significant areas of natural vegetation & 6.0 & 0.9 \\
\hline Continuous urban fabric & 12.9 & 0.35 \\
\hline Precipitation*** & & \\
\hline
\end{tabular}

*provinces: West Pomerania, Pomerania, Warmia-Masuria, Podlasie, Mazovia, Kujawy-Pomerania, Lublin, Świętokrzyskie, Silesia, Małopolska, Podkarpacie

**provinces: Lower Silesia, Lubuskie, Łódź, Opole, Wielkopolska

***regarding a lake's area only

the abiotic parameters of the water environment and biota and relate the results obtained to their spatial distribution [25].

The study used spatial data representing the situation and boundaries of Poland's national/landscape parks, lakes, lake catchments, and land cover. The first vector layer came from the Internet service of the European Environment Agency (EEA) [26]. Made available under a liberal licence, it illustrates the situation and boundaries of all the NPs, LPs, and nature reserves in our country. The layer presenting lakes in Poland's territory is part of the Hydrographic Map of Poland (HMP). This database was acquired from the National Water Management Authority (NWMA) [27]. The layer of total lake catchments was elaborated upon by verifying topographic catchments originating from the HMP database within the framework of the project called "The formulation of restrictions on the use of the waters of lakes or reservoirs and on the use of their catchments in the conditions for the use of the waters of a water region" in 2010 [28]. The verification process mainly consisted in including/excluding fragments of catchments (they were often areas encompassing sites without outflow) and "closing" of the catchments of lakes at their outflows based on 1:50,000 topographic maps in the 1965 PUWG Coordinate System. Poland's land cover was acquired from the CORINE Land Cover 2006 project [29].

Using the layers representing lakes and national/landscape parks, it was possible to calculate the ratios of the lake area to the catchment area for the individual protected areas. It was assumed that for the areas of the parks on the seacoast (Słowiński and Woliński National Parks) the ratios of the lake area to the catchment area should be calculated in reference to the terrestrial part of the park.
The lakes selected for analyses ( 92 water bodies) were those that represented significant water bodies within the meaning of the provisions of the WFD, i.e. with a surface area exceeding 50 ha [8]. The majority of them (58 lakes) are medium-sized lakes (50-200 ha). Almost 30\% (29 lakes) are large lakes (200.1-1,000 ha), the number of lakes with a surface area exceeding 1,000 ha is the smallest (5). In order to obtain as up-to-date information as possible on the ecological status of lakes in protected areas, use was made of NEMS data from 2010-12. The ecological status assessment contained in this study was carried out within the framework of the national lake monitoring; it was primarily based on an assessment of the ecological formations living in a lake ecosystem (mainly including phytoplankton, phytobenthos and macrophytes); the integration process took into account the decisive importance of the element in the worst status ("one out all out"), in an approach recommended by the Water Framework Directive, supported by an expert assessment [8]. Basic morphometric data were taken from the LAKES 2 database, along with the data on the quality of their waters expressing the intensity of eutrophication (the concentrations of chlorophyll $a$ and total fractions of nitrogen - TN and phosphorus - TP, as well as the Secchi depth). Samples for analyses of chlorophyll $a$ and chemical parameters were collected by the Voivodeship Inspectorates in the period from March/April to August/September, for most lakes three times (during spring mixing, early summer, summer stagnation) or four times a year (autumn mixing). The selected benchmark lakes were sampled 6-7 times a year at monthly intervals. Water samples were collected in the deepest part of the lake. During the summer stagnation period integrated water samples were collected from the epil- 


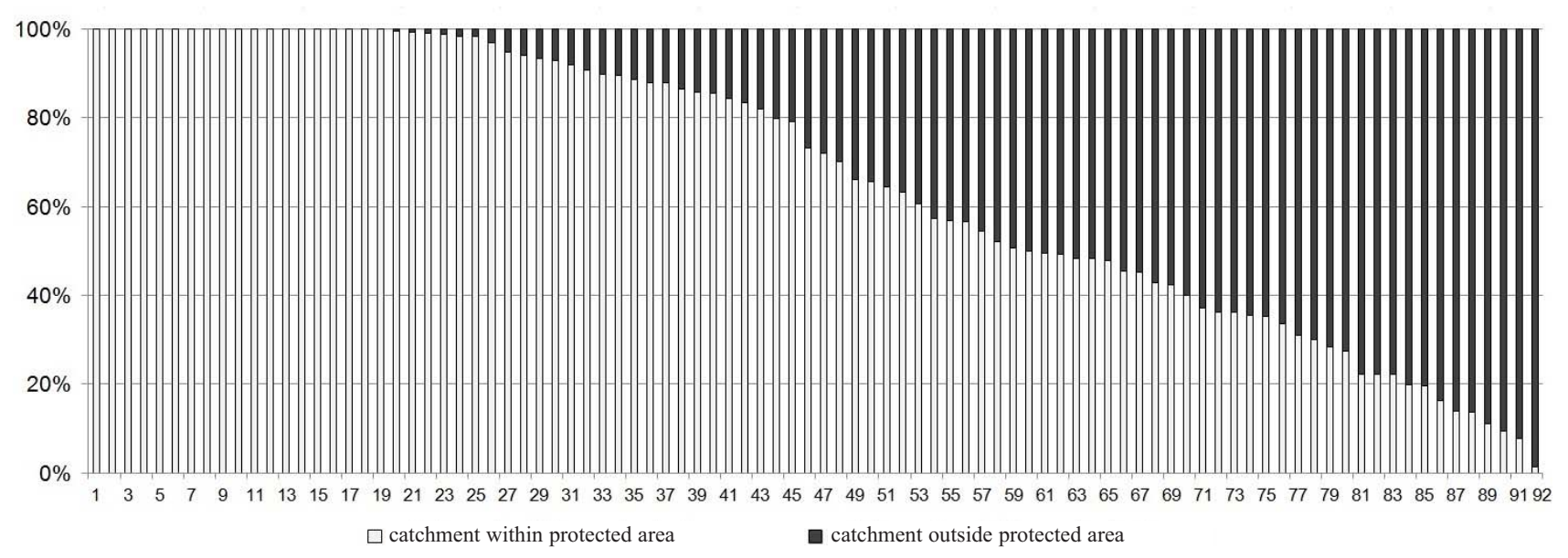

Fig. 1. The percentage share of a protected area in the surface area of the total catchment of the lakes analyzed (1-92 are the numbers of lakes).

imnion and in the spring and autumn from the euphotic layer. In polymictic lakes, integrated samples were taken from the $0-5 \mathrm{~m}$ layer.

The integrated assessment of the ecological status of lakes was carried out pursuant to the draft Regulation of the Minister of the Environment of 8 May 2013 [3]. Long-term trends of water quality change in the selected lakes were analyzed on the basis of archival NEMS data from 1999-2012.

Based on the unit $\mathrm{N}$ and $\mathrm{P}$ loads emerging in the catchment depending on the manner of its use, which were determined on the basis of the scientific literature used in the "The Formulation ..." project implemented on commission from the Regional Water Management Board in Kraków by the consortium MGGP S.A. and the IEP-NRI, with the participation of several dozen experts - limnologists in 2010 [28], analyses of the relation between the load theoretically emerging in the catchment on the nutrient concentrations in water and the ecological status of lakes were carried out. The calculations did not cover point sources of pollution. Table 1 shows the values of unit loads applied in the abovementioned project and used in the present study. In order to take into account in statistical analyses the nutrient loads that were theoretically generated in the catchment, along with the quantity of water in a lake - a significant morphometric factor - the nitrogen and phosphorus load was recalculated per the volume of lake waters in cubic metres.

Statistical analyses were performed with the StatSoft Statistica 8 for Windows. The non-parametric MannWhitney $U$ test was used to reveal which means of abiotic and biotic parameters are significantly different between two groups of lakes, characterized by at least good and a worse than good ecological status. The Spearman rank coefficient was used to determine the relationship between the abiotic and biotic parameters of water and catchment features.

\section{Results}

The extent to which the catchments of lakes with waters located in NPs and LPs are situated within their areas varies in a wide range. In the case of 42 lakes, the whole catch- ment or at least $80 \%$ of it is situated in a protected area. For 27 lakes, less than $80 \%$ of their catchments, but more than $40 \%$ lies in the protected area. The catchments of the other lakes are protected to a much lower degree (less than $40 \%$ within a park), while for the catchments of seven lakes the park area represents barely several or a dozen or so percent (Fig. 1). In general, the larger the surface area of the total lake catchment, the larger share of it covered by protection; still, at the same time, the percentage share of the catchment within the park boundaries decreases. As a result, the catchments of 10 lakes which are some of the largest ones (with a surface area of about 32,000 to 248,000 ha) are situated to a small extent within a park area (from $1 \%$ to about $30 \%$ ).

Out of 92 lakes analyzed, for 20 lakes there is a strong domination (i.e. more than $80 \%$ of the cover) of natural areas (forests, waters, and wetlands). In turn, more than $60 \%$ of the total catchments of two thirds of lakes were occupied by farmland (arable land, meadows, and pastures). Anthropogenic areas, i.e. mainly rural buildings, urban green areas, construction sites, and industrial areas, represent several to a dozen or so percent. An exception is Lake Krasne, where the rural buildings situated on its banks occupy more than $20 \%$ of the surface area of the total catchment. The comparison of the land use structure within landscape and national parks with the whole area of lake catchments indicates that natural areas, mostly forestland or wetlands, are more often covered by protection, whereas in the case where only part of a catchment is situated within a protected area, rural areas are located outside of it. Fig. 2 shows the structure of land use in the total lake catchments.

An ecological status assessment was carried out for $47 \%$ of all the lakes situated in landscape and national parks. Moreover, when their total surface area is considered, they represent $55 \%$ of the total surface area of these waters.

For the lakes analyzed, the indicators of eutrophication pressure reached very diversified values. The mean seasonal chlorophyll $a$ concentration varied between 1.5 and 187 $\mu \mathrm{g} / 1$ depending on the lake; this was reflected in the water transparency from $0.3 \mathrm{~m}$ to more than $7 \mathrm{~m}$ in terms of 

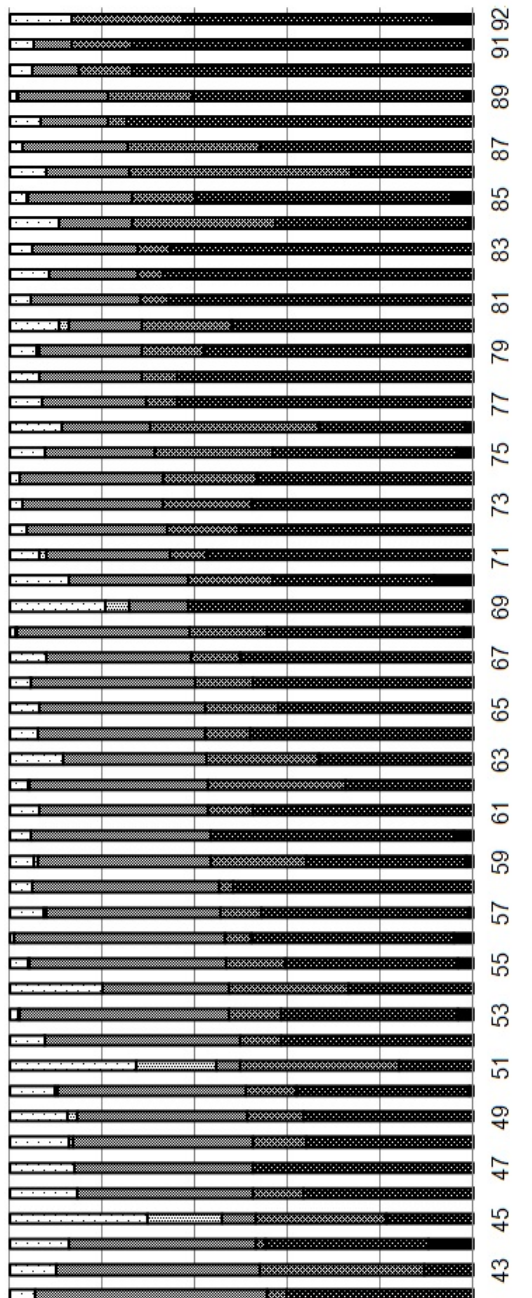

其
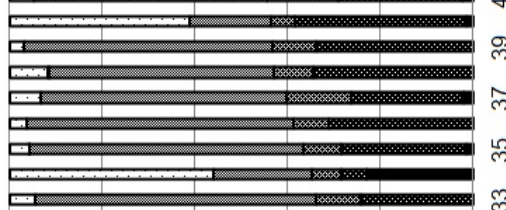

1
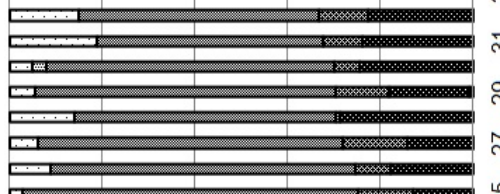

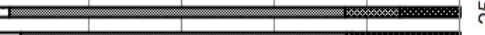
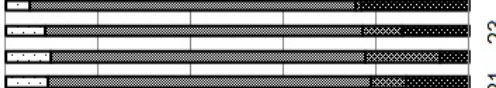

$-1$

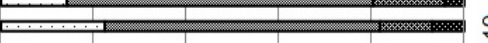

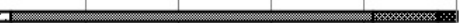

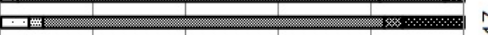

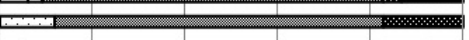

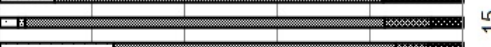
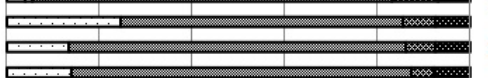

10

(1)
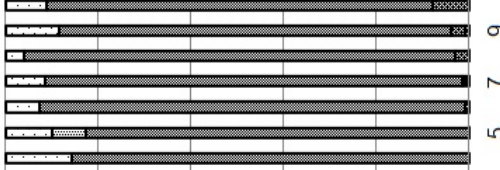

…. 1

1

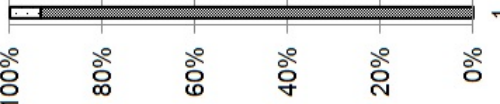

Secchi depth. The total nitrogen and phosphorus concentrations varied, respectively, from 0.55 to $5.35 \mathrm{mg} / \mathrm{l}$ and from 0.003 to $0.233 \mathrm{mg} / \mathrm{l}$.

Based on the above-mentioned parameters, it can be said that about half of the lakes in protected areas $(45 \%)$ are in at least good status and that most of them are characterized by moderate status, but $20 \%$ of them are in poor or bad status (Fig. 3). Only in three protected areas (Lagowski LP and Tucholskie Woods and Poleski National Parks) all lakes which are significant water bodies are in good or high ecological status. Also, in four parks (Wdzydzki, Drawski, and Górzniewsko-Lidzbarski LPs, and Wigierski NP), there are only lakes in at least good status, but no current data are available for some water bodies situated in them. Within all the other protected areas there are lakes in varied ecological status, also including those in a worse than good status (Table 6). No relationship was found between the form of protection, the date of its establishment, and the ecological status of the lakes situated in their areas. Lakes in a worse than good status can be found in the areas of both landscape and national parks established several dozen years ago (e.g. Lake Góreckie in Wielkopolski NP of or Lake Mikołajskie in Masurian LP) and those that have been in place for a dozen or so years (e.g. Lake Gołdap in Romincka Forest LP).

Since the areas of the total lake catchments covered by the protection varied, the relationship between the ecological status of the lakes and the size of their total catchment subject to protection was analyzed. No correlation was found between the percentage share of the catchment under protection and the eutrophication indicators (chlorophyll $a$, TN, TP, and Secchi depth), while the Spearman correlation coefficient varied between -0.06 and 0.13 and was statistically insignificant $(\mathrm{p}>0.05)$.

A strong correlation was found between the concentration of chlorophyll $a$ and the nutrients in water, water transparency, and the majority of limnological parameters characterizing the lake (Table 2). A negative correlation coefficient between the chlorophyll $a$ concentration and the morphometric indicators suggests that the chlorophyll $a$ concentration increases as the mean lake depth, water stratification, lake volume, and the ratio of its volume to the shore line length decrease. Moreover, the lower the val-

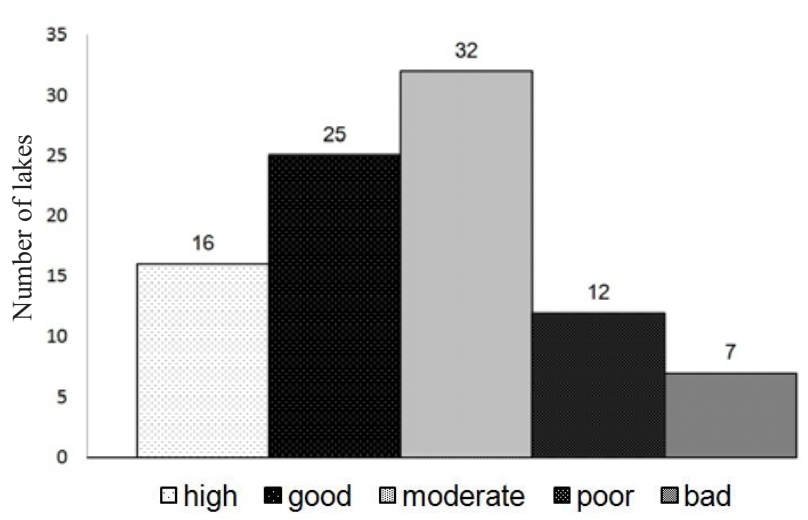

Fig. 3. The ecological status of lakes located in national and landscape parks. 
Table 2. Spearman rang correlation between limnological parameters and eutrophication indicators.

\begin{tabular}{|c|c|c|c|c|}
\hline $\begin{array}{l}\text { Limnological } \\
\text { parameters }\end{array}$ & $\begin{array}{c}\text { Chlorophyll } a \\
{[\mu \mathrm{g} / 1]}\end{array}$ & $\begin{array}{l}\text { Secchi depth } \\
{[\mathrm{m}]}\end{array}$ & $\begin{array}{c}\mathrm{TN} \\
{[\mathrm{mgN} / \mathrm{l}]}\end{array}$ & $\begin{array}{c}\mathrm{TP} \\
{[\mathrm{mgP} / \mathrm{l}]}\end{array}$ \\
\hline Mean depth [m] & -0.41 & 0.61 & -0.50 & -0.20 \\
\hline Lake surface [ha] & -0.11 & 0.21 & -0.14 & -0.06 \\
\hline $\mathrm{V} / \mathrm{L}^{*}\left[\right.$ thous.m $\left.\mathrm{m}^{3} / \mathrm{m}\right]$ & -0.38 & 0.51 & -0.42 & -0.21 \\
\hline Stratification [\%] & -0.42 & 0.59 & -0.47 & -0.24 \\
\hline Lake volume [thous. $\mathrm{m}^{3}$ ] & -0.28 & 0.46 & -0.37 & -0.12 \\
\hline Catchment surface [ha] & 0.23 & -0.09 & 0.01 & 0.24 \\
\hline Schindler's ratio** $\left[\mathrm{m}^{2} / \mathrm{m}^{3}\right]$ & 0.55 & -0.54 & 0.37 & 0.45 \\
\hline Lake coefficient $* * *$ & 0.37 & -0.24 & 0.13 & 0.35 \\
\hline Water exchange [\%] & 0.48 & -0.47 & 0.32 & 0.43 \\
\hline
\end{tabular}

Results statistically significant are in bold $(\mathrm{p}<0.05)$

* Ratio of the volume of lake to length of lake shoreline

** Ratio of the total catchment's area to the volume of lake

*** Ratio of the total catchment area to the lake area

Table 3. The differentiation of the limnological parameters in the group of the lakes in at least good and worse than good status. The statistical significance according to the Mann-Whitney U test.

\begin{tabular}{|c|c|c|c|c|c|}
\hline \multirow{3}{*}{ Limnological parameters } & \multicolumn{4}{|c|}{ Ecological status } & \multirow{3}{*}{$\mathrm{p}$} \\
\hline & \multicolumn{2}{|c|}{ At least good $(n=41)$} & \multicolumn{2}{|c|}{ Worse than good $(n=51)$} & \\
\hline & Mean (max-min) & S.D. & Mean (max-min) & S.D. & \\
\hline Lake coefficient & $25.9(2.5-112.3)$ & 26.8 & $81.6(2.2-962.7)$ & 153.7 & 0.000 \\
\hline Mean depth [m] & $8.6(0.6-38.7)$ & 6.7 & $5.7(1.1-20.7)$ & 3.7 & 0.020 \\
\hline $\mathrm{V} / \mathrm{L}\left[\right.$ thous. $\left.\mathrm{m}^{3} / \mathrm{m}\right]$ & $2.3(0.1-10.2)$ & 2.2 & $1.2(0.2-5.0)$ & 1.1 & 0.007 \\
\hline Stratyfication [\%] & $19.7(0.0-77.5)$ & 21.0 & $9.2(0.0-58.6)$ & 12.7 & 0.014 \\
\hline Water exchange [\%] & $63(0-550)$ & 94.3 & $390(3.0-7700)$ & 1217.0 & 0.000 \\
\hline Schindler's ratio $\left[\mathrm{m}^{2} / \mathrm{m}^{3}\right]$ & $4.0(0.3-17.1)$ & 4.2 & $24.6(0.2-444.5)$ & 69.6 & 0.020 \\
\hline
\end{tabular}

ues of the above-mentioned morphometric parameters, the less transparent the waters. The catchment parameters applied and the percentage rate of water exchange correlated positively with the value of chlorophyll $a$. The chlorophyll $a$ concentration was the higher, the larger surface area of the total catchment of the lake was $(r=0.23$, $\mathrm{p}<0.05$ ), while the impact of the size of the catchment was even more strongly expressed by the lake coefficient $(\mathrm{r}=0.37, \mathrm{p}<0.05)$ and the ratio of the catchment area to the volume of lake waters $(\mathrm{r}=0.55, \mathrm{p}<0.05)$. The chlorophyll $a$ concentration was also enhanced by greater water exchange $(r=0.48, p<0.05)$. Similar trends of change could also be observed between the limnological features of lakes and the mean seasonal nutrient concentrations in their waters (Table 2).

It is important to note the statistically significant differences between the mean values and the range of selected limnological parameters in lakes in high or good ecological status and those in lakes in a worse than good status (Table 3 ). The group of lakes in at least good status is more differ- entiated than the group of lakes in a worse than good status in terms of their mean depth (S.D.= 6.7 ver. 3.7), water stratification degree (S.D. $=21.0$ ver. 12.7 ), and the $\mathrm{V} / \mathrm{L}$ ratio (S.D.=2.2 ver. 1.1), while the mean values of the abovementioned parameters are higher for the former of these groups. In contrast, in the case of Schindler's ratio, lake coefficient and the rate of water exchange, their range of variation in the group of lakes in at least good status was smaller (respectively S.D. $=4.2,26.8,94.3$ ) than that for lakes that had not reached good status (respectively S.D.= $69.6,153.7,1217.0$ ), while their mean value was significantly lower (Table 3).

It can be noted that the total catchments of lakes the status of which was classified as high and good had on average about $10-20 \%$ more natural areas (forests, wetland, and waters) than those of lakes the status of which was classified as worse than good (Fig. 4). It is important to note the differentiation of the mean catchment areas of lakes in different status. A larger mean catchment area is characteristic of a group of lakes in poor or bad ecological status. 
Table 4. Spearman rang correlation between types of land use and eutrophication indicators.

\begin{tabular}{|l|l|c|c|c|c|}
\hline \multicolumn{2}{|c|}{ Type of land use } & $\begin{array}{c}\text { Chlorophyll } a \\
{[\mu \mathrm{g} / \mathrm{l}]}\end{array}$ & $\begin{array}{c}\text { Secchi depth } \\
{[\mathrm{m}]}\end{array}$ & $\begin{array}{c}\text { TN } \\
{[\mathrm{mgN} / \mathrm{l}]}\end{array}$ & $\begin{array}{c}\text { TP } \\
{[\mathrm{mgP} / \mathrm{l}]}\end{array}$ \\
\hline \multirow{4}{*}{ Total catchment } & Antropogenic [\%] & -0.04 & 0.07 & 0.05 & 0.01 \\
\cline { 2 - 6 } & Agricultural [\%] & 0.09 & 0.02 & 0.18 & -0.05 \\
\cline { 2 - 6 } & Natural [\%] & -0.17 & 0.12 & -0.10 & 0.20 \\
\hline \multirow{3}{*}{$\begin{array}{l}\text { Catchment within a } \\
\text { protected area }\end{array}$} & Antropogenic [\%] & -0.04 & 0.07 & 0.06 & 0.05 \\
\cline { 2 - 6 } & Agricultural [\%] & 0.10 & 0.11 & $\mathbf{0 . 2 1}$ & 0.06 \\
\cline { 2 - 6 } & Natural [\%] & -0.14 & 0.00 & -0.14 & 0.10 \\
\hline
\end{tabular}

Results statistically significant are bold $(\mathrm{p}<0.05)$.

Table 5. Spearman rang correlation between the total sum of nutrients` loads theoretically generated in the catchment regarding types of land use and the eutrophication indicators.

\begin{tabular}{|l|c|c|c|c|}
\hline $\begin{array}{c}\text { Total nutrient load (N+P) } \\
{\left[\mathrm{g} / \mathrm{m}^{3} / \mathrm{year}\right]}\end{array}$ & $\begin{array}{c}\text { Chlorophyll } a \\
{[\mu \mathrm{g} / \mathrm{l}]}\end{array}$ & $\begin{array}{c}\text { Secchi depth } \\
{[\mathrm{m}]}\end{array}$ & $\begin{array}{c}\text { TN } \\
{[\mathrm{mgN} / \mathrm{l}]}\end{array}$ & $\begin{array}{c}\text { TP } \\
{[\mathrm{mgP} / \mathrm{l}]}\end{array}$ \\
\hline Total catchment & $\mathbf{0 . 5 3}$ & $\mathbf{- 0 . 5 1}$ & $\mathbf{0 . 4 4}$ & 0.33 \\
\hline Antropogenic & $\mathbf{0 . 2 2}$ & -0.15 & 0.12 & 0.09 \\
\hline Agricultural & $\mathbf{0 . 4 2}$ & $\mathbf{- 0 . 3 3}$ & $\mathbf{0 . 3 5}$ & 0.18 \\
\hline Natural & $\mathbf{0 . 5 7}$ & $\mathbf{- 0 . 5 7}$ & $\mathbf{0 . 2 8}$ & $\mathbf{0 . 4 4}$ \\
\hline
\end{tabular}

Results statistically significant are bold $(\mathrm{p}<0.05)$.

The smallest catchment areas in relation to the whole set of lakes are usually those of the lakes that have been classified as high (Fig. 4). However, the differentiation of the total catchments of the lakes analyzed in terms of the percentage shares of different uses does not demonstrate a statistically significant correlation with the eutrophication parameters or with the ecological status of lakes (Table 4). A slight ( $\mathrm{r}=0.21$, $\mathrm{p}<0.05$ ) but statistically significant relationship was found only between the percentage share of farmland within parks and the mean concentration of total nitrogen in water.

The amounts of nitrogen and phosphorus loads theoretically emerging in the catchments of lakes situated in pro-

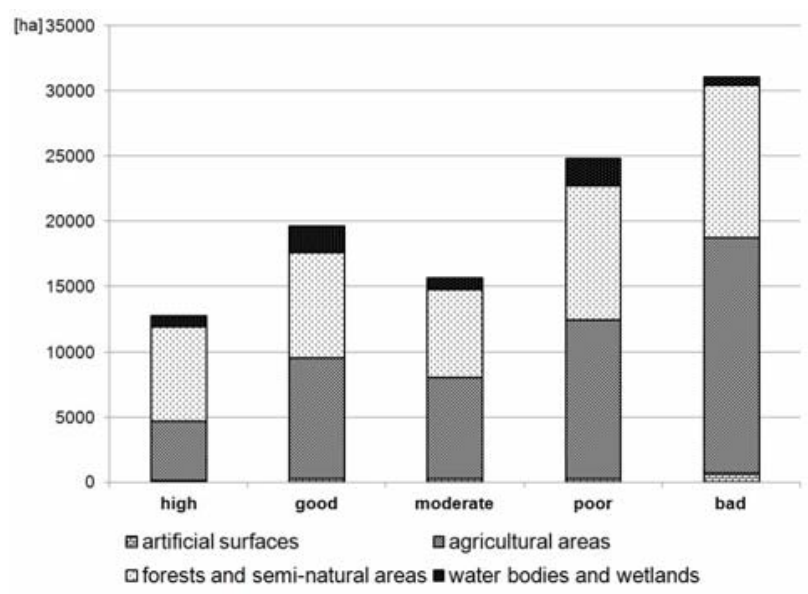

Fig. 4. The shares of different uses of the total catchment areas of the lakes analyzed, considering their ecological status. tected areas were very different. The total nutrient load $(\mathrm{N}$ and P) varied from about 1,500 to about $800,000 \mathrm{~kg}$. An exception was Lake Wielkie in Lubuskie Province within the catchment of which the theoretically emerging nutrient load reached a level of more than 1.2 million $\mathrm{kg}$. The lowest total load discharged in runoffs was $0.06 \mathrm{~g} / \mathrm{m}^{3} /$ year, whereas the highest one was $298 \mathrm{~g} / \mathrm{m}^{3} / \mathrm{year}$. The estimated nutrient load emerging in the total catchment correlated positively with the nutrient concentrations in water $(\mathrm{r}=0.44$ and $\mathrm{r}=0.33$ with $\mathrm{p}<0.05$, respectively for $\mathrm{TN}$ and $\mathrm{TP}$ ), as well as with the chlorophyll $a$ concentration $(\mathrm{r}=0.53$, $\mathrm{p}<0.05)$ and negatively with water transparency $(\mathrm{r}=-0.51$, $\mathrm{p}<0.05$ ) (Table 5).

The mean nitrogen and phosphorus load potentially emerging in farmland and in areas with natural cover in the catchments of lakes classified as ones in high or good status was significantly lower than the analogous load calculated for lakes in worse than good status. The variability of the total loads in the catchments of individual lakes, given in figures as the minimum and maximum values, was much lower in the case of lakes in at least good status than in the group of those in worse than good status (Fig. 5).

In order to identify the possible impact of the date when a lake was incorporated into the area of a national/landscape park on the ecological status of an aqueous ecosystem, long-term variations in the chlorophyll $a$ concentrations were analyzed for four reference lakes where annual monitoring surveys are carried out (Fig. 6).

Two of them, North Lake Jasień and South Lake Jasien, have remained within the Stupia Valley LP since 1981. 
Available data indicate that the chlorophyll $a$ concentration fell in recent years. In the case of North Lake Jasien, the boundary chlorophyll value between good and moderate status was exceeded only in 2003 (when the concentration
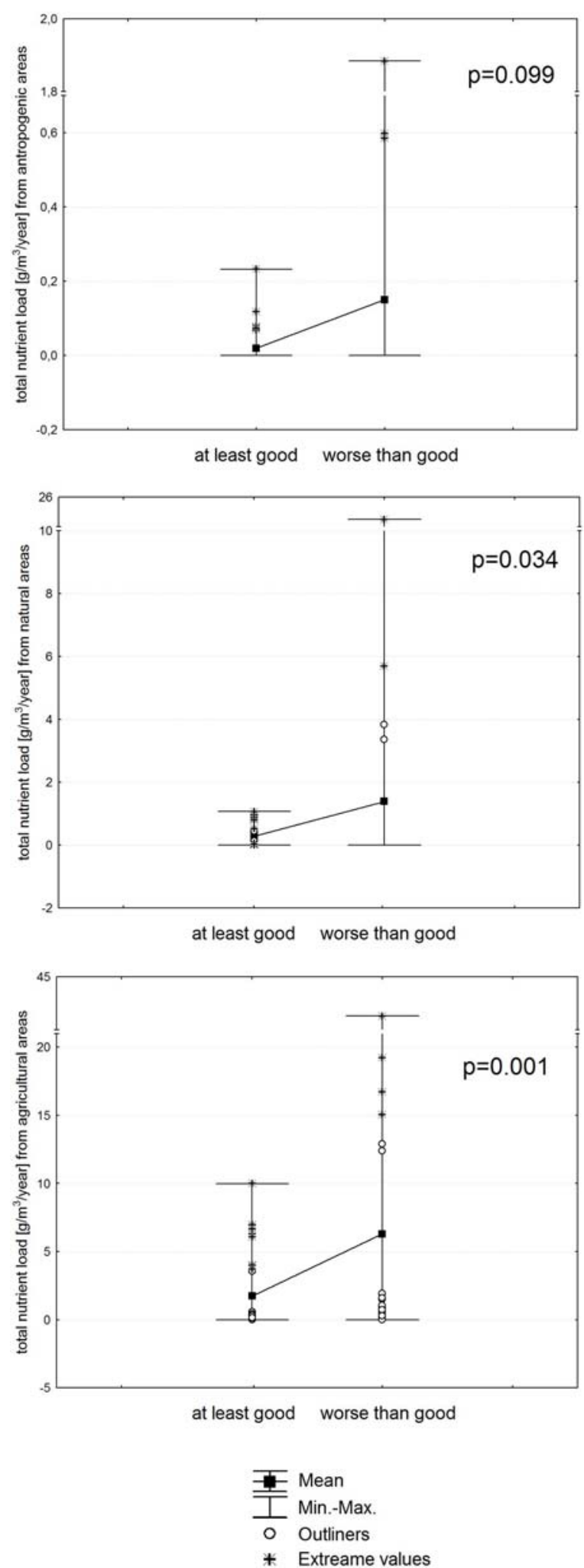

Fig. 5. The differentiation of the levels of nitrogen and phosphorous loads emerging in the areas of the major uses (mean, minimum and maximum) in the group of lakes in at least good and worse than good status. The statistical significance according to the Mann-Whitney U test. increased to about $15 \mu \mathrm{g} / \mathrm{l}$ ), while South Lake Jasień remained in a worse than good status in 1999-2008. In Lake Śremskie, protected within Sierakowski LP since 1991, there is no clear trend of variations in the mean chlorophyll $a$ concentration. In the years under analysis, its concentration varied from 3 to $11 \mu \mathrm{g} / 1$, exceeding the good-moderate boundary in several years. Lake Długie Wigierskie within Wigierski NP is characterized by good status, but it shows a weak tendency for the chlorophyll $a$ concentration to increase and once (in 2011) its value increased to about 15 $\mu \mathrm{g} / \mathrm{l}$, indicating moderate ecological status (Fig. 6).

\section{Discussion}

About $14 \%$ of Polish lakes with a surface area of more than 1 ha are situated within the landscape and national parks, including 200 lakes with a surface of more than 50 ha $(2.8 \%$ of Polish lakes). The maximum ratio of the lake area to the catchment area in national parks is $44.3 \%$ (Słowiński NP), whereas for landscape parks it is $27.4 \%$ (Masurian LP).

Although the lakes analyzed are water bodies situated in areas with outstanding natural values, their ecological status is close to the distribution characteristic of the results of an assessment of the ecological status of lakes originating from an annual monitoring of lakes that covers lakes from different regions of Poland [30]. About 50\% of the lakes analyzed are in at least good status. However, about $20 \%$ is even in poor and bad ecological status. On the basis of the above data, it is impossible to observe a positive impact of the integration of the lakes analyzed into parks, which would consist of the maintenance or restoration of good ecological status, as a general principle.

A significant relationship was found between ecological status and morphometric, hydrological, and catchmentrelated factors (mean depth, water stratification, water exchange in a year, Schindler's ratio, and the lake coefficient). They determine the natural susceptibility of lakes to degradation and they have been taken into account in the lake quality classification systems $[6,7,11]$.

It was assumed that there is a relationship between catchment use and lake water quality [12, 14, 19, 31, 32]. Catchment area use can potentially enhance or reduce the strength and type of the impact of the catchment on the lake. Its use can be a sort of an anthropogenic factor that intensifies matter supply from the catchment and, thereby, a deterioration of the ecological status of a lake; as a natural factor, it can also affect the susceptibility of the lake to degradation $[33,34]$.

Land use in a catchment is an important factor that affects the levels of nitrogen and phosphorus loads discharged into surface waters that stimulate water eutrophication. The lost fertilizer components or the field crop production techniques applied are the basic sources of nitrogen and phosphorus loads going into waters, particularly from catchments of agricultural character $[12,15]$.

Modern approaches to the protection of aquatic ecosystems located in protected areas underline the need to apply 
preventive methods in the whole area of a catchment [3537]. Protection activities should include not only appropriate development of water supply and wastewater systems, to limit river and water pollution, but also changes in land use, i.e. a partial or total elimination of mineral fertilization of arable lands, changes of plant cover, and the establishment of plant barriers protecting lakes and rivers [35]. It should be expected that more rigorous conditions for managing the catchments of lakes situated in protected areas (e.g. restrictions on building in the lakeside zone and those on fertilization) would be reflected in the maintenance or restoration of good ecological status of their waters, especially if all the catchment area is situated within a national or landscape park. Comparative analyses of the ecological status of lakes situated in protected areas show that a lake can be in a worse than good status, also including bad ecological status (e.g. Lakes Chłop, Kłosowskie, and Mieliwo), even if the entire or almost entire (> 80\%) catchment of wooded character is also covered by a protected area. In the case of each of the abovementioned lakes, the explanation of the causes of a deterioration of the status of the ecosystem requires additional information. Catchments consisting of natural or semi-natural areas are subjected to lower human pressures and hence contribute to a lesser extent to an acceleration of the eutrophication process. It can be expected that lakes where the catchments are dominated by forests would have the reference, high or good water status. However, neglecting the assessment error, the causes of degradation of lake ecosystems can include, e.g., point sources related to the development of the lakeside zone for tourism purposes (inappropriate fishery) and unregulated wastewater management, or even large cormorant populations feeding on the lake and enriching it with organic matter $[4,15,38]$. Apart from nutrient loads, factors that intensify the eutrophication of water bodies can also be hydrological or climatic [3,39]. Water level fluctuations caused by changes in the littoral range and the depth of the lake influence water biota assemblages and the ecological status of a lake $[40,41]$. Therefore, the group of water bodies the catchments of which are for the most part covered by natural areas (more than $60 \%$ of their area) include lakes representing each of the five possible ecological statuses.

In the case of lakes with an agricultural catchment, even if the whole catchment is covered by protection in a park, this does not ensure that good ecological status of a lake is maintained. Lakes in protected areas can receive such large amounts of nutrients from an agricultural catchment that their ecological status abruptly becomes worse or at least no improvement is possible [e.g. 15, 31]. It also happens that lakes with a catchment dominated by arable land and situated within a park to a slight extent only $(<20 \%)$ can be in good or high ecological status. Lakes where the catchments of which are dominated by farmland are to a large degree protected against runoff of nitrogen and phosphorus compounds from the fields by an extensive buffer zone covered
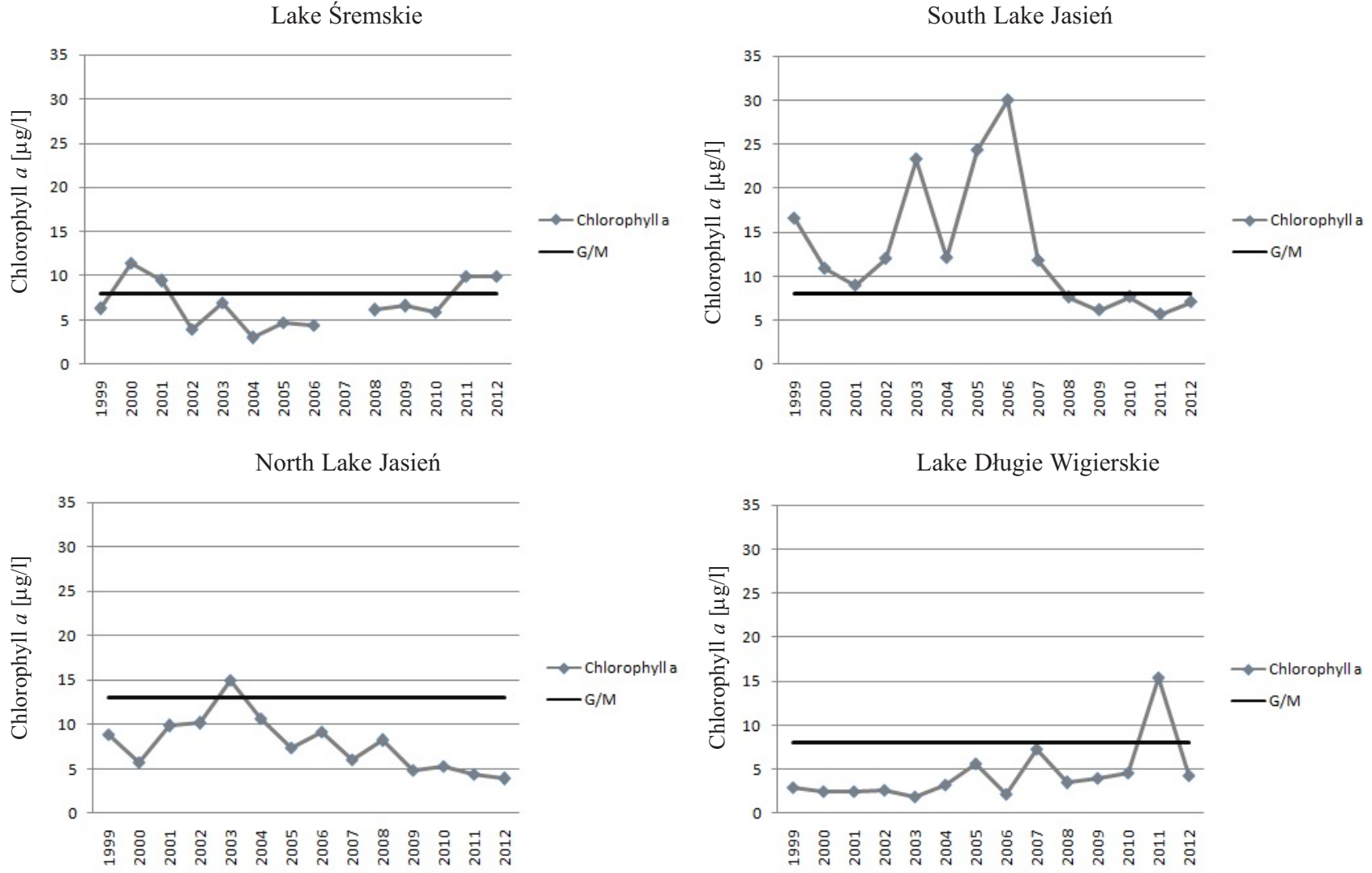

Fig. 6. Long-term variations (1999-2012) in the mean seasonal chlorophyll a concentrations in select reference lakes (G/M good/moderate boundary of ecological status). 
Table 6. The list of lakes in national and landscape parks - limnological characteristics and ecological status.

\begin{tabular}{|c|c|c|c|c|c|c|c|}
\hline ID & Lake name & Form of protection & $\begin{array}{c}\text { Date of } \\
\text { establishment }\end{array}$ & $\begin{array}{c}\text { Lake area } \\
\text { [ha] }\end{array}$ & $\begin{array}{c}\text { Max. } \\
\text { depth }[\mathrm{m}]\end{array}$ & $\begin{array}{c}\text { Mean } \\
\text { depth }[\mathrm{m}]\end{array}$ & $\begin{array}{c}\text { Ecological } \\
\text { status }\end{array}$ \\
\hline 10141 & Góreckie & Wielkopolska NP & 1957 & 104.2 & 17.2 & 8.5 & moderate \\
\hline 21045 & Łebsko & Słowiński NP & 1967 & 7140.0 & 6.3 & 1.6 & moderate \\
\hline 30614 & Hańcza & Suwalski LP & 1976 & 311.4 & 108.5 & 38.7 & high \\
\hline 30265 & Jegocin & Masurian LP & 1977 & 127.4 & 36.1 & 9.0 & high \\
\hline 30224 & Kołowin & Masurian LP & 1977 & 78.2 & 7.2 & 4.0 & high \\
\hline 30174 & Kuc & Masurian LP & 1977 & 98.8 & 28.0 & 8.0 & good \\
\hline 30235 & Łuknajno & Masurian LP & 1977 & 680.0 & 3.0 & 0.6 & high \\
\hline 30168 & Majcz Wielki & Masurian LP & 1977 & 163.5 & 16.4 & 6.0 & good \\
\hline 30175 & Mikołajskie & Masurian LP & 1977 & 497.9 & 25.9 & 11.2 & poor \\
\hline 30219 & Mokre & Masurian LP & 1977 & 841.0 & 51.0 & 12.7 & moderate \\
\hline 30234 & Śniardwy & Masurian LP & 1977 & 11340.4 & 23.4 & 5.8 & good \\
\hline 10708 & Siecino & Drawski LP & 1979 & 729.7 & 44.3 & 14.1 & good \\
\hline 10682 & Żerdno & Drawski LP & 1979 & 205.0 & 36.0 & 15.2 & good \\
\hline 20056 & Goreńskie & Gostynińsko-Włocławski LP & 1979 & 55.3 & 6.1 & 3.0 & good \\
\hline 20007 & Lucieńskie & Gostynińsko-Włocławski LP & 1979 & 201.3 & 20.0 & 8.3 & poor \\
\hline 21008 & Jasień Płd. & LP Doliny Słupi & 1981 & 336.7 & 22.6 & 7.5 & good \\
\hline 21009 & Jasień Płn. & LP Doliny Słupi & 1981 & 240.5 & 32.2 & 9.1 & good \\
\hline 21000 & Skotawsko Wielkie & LP Doliny Słupi & 1981 & 80.0 & 8.7 & 4.1 & moderate \\
\hline 20720 & Brodno Wielkie & Kaszubski LP & 1983 & 134.1 & 15.7 & 6.6 & good \\
\hline 20715 & Raduńskie Dolne & Kaszubski LP & 1983 & 737.2 & 35.4 & 11.2 & moderate \\
\hline 30725 & Spólne & Sobiborski LP & 1983 & 65.3 & 2.3 & 1.4 & moderate \\
\hline 20503 & Wdzydze Południowe & Wdzydzki LP & 1983 & 918.8 & 68.0 & 18.7 & good \\
\hline 20189 & Bachotek & Brodnicki LP & 1985 & 211.0 & 24.3 & 7.2 & moderate \\
\hline 20181 & Dębno & Brodnicki LP & 1985 & 59.5 & 15.9 & 5.5 & moderate \\
\hline 20193 & Mieliwo & Brodnicki LP & 1985 & 80.9 & 9.4 & 3.4 & moderate \\
\hline 20175 & Partęczyny Wielkie & Brodnicki LP & 1985 & 323.9 & 28.5 & 6.8 & moderate \\
\hline 10066 & Trześniowskie & Łagowski LP & 1985 & 185.7 & 58.8 & 19.3 & good \\
\hline 10067 & Łagowskie & Łagowski LP & 1985 & 82.4 & 13.5 & 5.3 & good \\
\hline 20299 & Ostrowite & NP Bory Tucholskie & 1985 & 280.7 & 43.0 & 10.7 & high \\
\hline 20381 & Długie & Tucholski LP & 1985 & 64.0 & 9.3 & 3.6 & moderate \\
\hline 20532 & Okonińskie & Tucholski LP & 1985 & 106.5 & 24.5 & 8.8 & good \\
\hline 20408 & Szpitalne & Tucholski LP & 1985 & 66.4 & 19.6 & 7.5 & good \\
\hline 10329 & Białe & Pszczewski LP & 1986 & 55.6 & 11.5 & 5.7 & good \\
\hline 10360 & Chłop & Pszczewski LP & 1986 & 227.8 & 23.0 & 9.0 & moderate \\
\hline 10354 & Konin & Pszczewski LP & 1986 & 93.5 & 4.3 & 2.1 & bad \\
\hline 10332 & Lubikowskie & Pszczewski LP & 1986 & 314.7 & 35.5 & 10.9 & high \\
\hline 10333 & Rokitno & Pszczewski LP & 1986 & 61.5 & 10.2 & 5.1 & high \\
\hline 10327 & Szarcz & Pszczewski LP & 1986 & 169.8 & 14.5 & 7.9 & high \\
\hline 10362 & Wędromierz & Pszczewski LP & 1986 & 73.8 & 11.8 & 4.9 & moderate \\
\hline 10353 & Wielkie & Pszczewski LP & 1986 & 188.7 & 3.7 & 2.1 & bad \\
\hline
\end{tabular}


Table 6. Continued.

\begin{tabular}{|c|c|c|c|c|c|c|c|}
\hline ID & Lake name & Form of protection & $\begin{array}{c}\text { Date of } \\
\text { establishment }\end{array}$ & $\begin{array}{c}\text { Lake area } \\
\text { [ha] }\end{array}$ & $\begin{array}{c}\text { Max. } \\
\text { depth }[\mathrm{m}]\end{array}$ & $\begin{array}{c}\text { Mean } \\
\text { depth }[\mathrm{m}]\end{array}$ & $\begin{array}{c}\text { Ecological } \\
\text { status }\end{array}$ \\
\hline 30619 & Dhugie Wigierskie & Wigierski NP & 1989 & 80.0 & 14.8 & 7.4 & good \\
\hline 30626 & Pierty & Wigierski NP & 1989 & 228.2 & 38.0 & 10.4 & good \\
\hline 30616 & Wigry & Wigierski NP & 1989 & 2118.3 & 73.0 & 15.9 & good \\
\hline 10787 & Ostrowiec & Drawieński NP & 1990 & 387.6 & 28.5 & 9.4 & good \\
\hline 20171 & Leźno Wielkie & Górznieńsko-Lidzbarski LP & 1990 & 86.2 & 14.5 & 5.5 & good \\
\hline 30703 & Bikcze & LP Pojezierze Łęczyńskie & 1990 & 85.0 & 3.3 & 1.5 & high \\
\hline 30700 & Kleszczów & LP Pojezierze Łęczyńskie & 1990 & 53.9 & 2.3 & 1.3 & high \\
\hline 30691 & Krasne & LP Pojezierze Łęczyńskie & 1990 & 75.9 & 33.0 & 10.7 & poor \\
\hline 30690 & Łukcze & LP Pojezierze Łęczyńskie & 1990 & 57.0 & 8.9 & 3.6 & moderate \\
\hline 30692 & Piaseczno & LP Pojezierze Łęczyńskie & 1990 & 84.7 & 38.8 & 10.8 & high \\
\hline 30689 & Rogóżno & LP Pojezierze Łęczyńskie & 1990 & 56.8 & 25.4 & 7.2 & moderate \\
\hline 30694 & Uścimowskie & LP Pojezierze Łęczyńskie & 1990 & 66.3 & 4.4 & 2.7 & moderate \\
\hline 30704 & Uściwierz & LP Pojezierze Łęczyńskie & 1990 & 284.1 & 6.6 & 3.2 & high \\
\hline 30706 & Łukie & Poleski NP & 1990 & 150.1 & 6.5 & 1.8 & high \\
\hline 20290 & Charzykowskie & Zaborski LP & 1990 & 1363.8 & 30.5 & 9.8 & moderate \\
\hline 20329 & Kruszyńskie & Zaborski LP & 1990 & 461.3 & 7.0 & 3.1 & moderate \\
\hline 20342 & Laska & Zaborski LP & 1990 & 70.4 & 3.6 & 1.4 & poor \\
\hline 11025 & Barlineckie & Barlinecko-Gorzowski LP & 1991 & 259.1 & 18.0 & 7.1 & high \\
\hline 10896 & Chłop & Barlinecko-Gorzowski LP & 1991 & 64.3 & 16.0 & 6.4 & moderate \\
\hline 10892 & Lubie & Barlinecko-Gorzowski LP & 1991 & 79.4 & 8.9 & 4.5 & moderate \\
\hline 10029 & Białe-Miałkie & Przemęcki LP & 1991 & 104.4 & 10.2 & 1.9 & bad \\
\hline 10017 & Dominickie & Przemęcki LP & 1991 & 343.9 & 17.1 & 6.5 & good \\
\hline 10025 & Lgińsko & Przemęcki LP & 1991 & 68.6 & 16.9 & 7.0 & moderate \\
\hline 10022 & Przemęckie Północne & Przemęcki LP & 1991 & 243.4 & 5.0 & 1.6 & poor \\
\hline 10031 & Przemęckie Zachodnie & Przemęcki LP & 1991 & 220.2 & 5.6 & 3.2 & poor \\
\hline 10295 & Barlin & Sierakowski LP & 1991 & 103.2 & 3.2 & 1.5 & bad \\
\hline 10274 & Białkowskie & Sierakowski LP & 1991 & 145.9 & 31.4 & 9.6 & bad \\
\hline 10273 & Chrzypskie & Sierakowski LP & 1991 & 304.3 & 15.0 & 6.1 & moderate \\
\hline 10287 & Jaroszewskie & Sierakowski LP & 1991 & 92.2 & 35.7 & 14.2 & good \\
\hline 10294 & Kłosowskie & Sierakowski LP & 1991 & 137.8 & 14.3 & 3.9 & poor \\
\hline 10286 & Kubek & Sierakowski LP & 1991 & 69.0 & 3.8 & 2.0 & poor \\
\hline 10285 & Lutomskie & Sierakowski LP & 1991 & 172.7 & 15.0 & 6.7 & poor \\
\hline 10301 & Ławickie & Sierakowski LP & 1991 & 90.1 & 17.2 & 7.3 & moderate \\
\hline 10292 & Śremskie & Sierakowski LP & 1991 & 117.6 & 45.0 & 20.2 & moderate \\
\hline 10276 & Wielkie & Sierakowski LP & 1991 & 260.8 & 30.1 & 9.6 & poor \\
\hline 10129 & Zbęchy & $\begin{array}{l}\text { LP im. gen. Dezyderego } \\
\text { Chłapowskiego }\end{array}$ & 1992 & 108.9 & 8.5 & 4.3 & bad \\
\hline 20566 & Gardzień & LP Pojezierza Iławskiego & 1993 & 85.5 & 2.1 & 1.2 & high \\
\hline 20754 & Januszewskie & LP Pojezierza Iławskiego & 1993 & 104.0 & 2.0 & 1.2 & poor \\
\hline 20120 & Płaskie & LP Pojezierza Iławskiego & 1993 & 620.4 & 5.7 & 2.4 & poor \\
\hline 20150 & Kiełpińskie & Welski LP & 1995 & 60.8 & 11.0 & 6.1 & good \\
\hline
\end{tabular}


Table 6. Continued.

\begin{tabular}{|c|c|c|c|c|c|c|c|}
\hline ID & Lake name & Form of protection & $\begin{array}{c}\text { Date of } \\
\text { establishment }\end{array}$ & $\begin{array}{c}\text { Lake area } \\
{[\text { ha] }}\end{array}$ & $\begin{array}{c}\text { Max. } \\
\text { depth }[\mathrm{m}]\end{array}$ & $\begin{array}{c}\text { Mean } \\
\text { depth [m] }\end{array}$ & $\begin{array}{c}\text { Ecological } \\
\text { status }\end{array}$ \\
\hline 20415 & Lutowskie & Krajeński LP & 1998 & 143.2 & 12.1 & 3.8 & moderate \\
\hline 10492 & Stryjewskie & Krajeński LP & 1998 & 151.2 & 16.7 & 7.5 & moderate \\
\hline 10501 & Więcborskie & Krajeński LP & 1998 & 194.0 & 18.5 & 8.3 & moderate \\
\hline 10486 & Zakrzewskie & Krajeński LP & 1998 & 66.6 & 7.5 & 3.9 & moderate \\
\hline 10059 & Borak & Krzesiński LP & 1998 & 62.0 & 8.4 & 4.0 & bad \\
\hline 30576 & Gołdap & LP Puszczy Rominckiej & 1998 & 149.0 & 10.9 & 5.6 & poor \\
\hline 10398 & Budzisławskie & Powidzki LP & 1998 & 140.8 & 35.2 & 10.8 & high \\
\hline 10416 & Kamienieckie & Powidzki LP & 1998 & 232.5 & 18.5 & 8.8 & good \\
\hline 10409 & Niedziegiel & Powidzki LP & 1998 & 550.9 & 21.5 & 5.5 & moderate \\
\hline 10102 & Powidzkie & Powidzki LP & 1998 & 1035.9 & 45.4 & 12.7 & good \\
\hline 10101 & Powidzkie Małe & Powidzki LP & 1998 & 52.0 & 7.5 & 3.5 & moderate \\
\hline 10401 & Wilczyńskie & Powidzki LP & 1998 & 173.8 & 23.2 & 7.3 & moderate \\
\hline
\end{tabular}

by natural vegetation (lakes Pierty and Szpitalne). The importance of buffer zones as barriers for water protection was emphasized by Hillbricht-Ilkowska [3]. In an agricultural landscape, the high efficiency of buffer zones in reducing nutrient runoffs was described Skwierawski et al. [42]. Morphometric conditions, such as substantial depth in the case of Lake Hańcza, are another factor that enhances the resilience of a lake to degradation. Nevertheless, large organic loads may cause a deterioration of the oxygen conditions in the meta - and hympolimnion and eventually contribute to intensified internal loading with nutrients, increasing the vulnerability of Lake Hańcza to eutrophication [24].

This study did not find a relationship between the percentage shares of the major uses of lake catchments and the ecological status of lakes. There are different land uses in the catchments of lakes that are in at least good status and those below good status. At the same time, good or high status of a water body can be met more often in the case of lakes with a smaller total catchment. It seems justified to explore the causes of extreme cases, i.e. such in which, despite their high resilience to degradation and their location, along with their catchment, within a protected area, lakes do not achieve good ecological status while, conversely, good status is characteristic of lakes affected by adverse catchment-related factors and vulnerable to nutrient runoffs.

Some lakes in the analyzed set lie within parks with a long tradition (those established 40-50 years ago), while others are located in areas covered by protection for a shorter period, but not less than 15 years. The analysis of longterm measurement series does not show a relationship between the date when an NP or LP was established and the improvement in the quality status of lakes situated within parks. This observation is probably not limited only to Polish protected areas and concerns, for example English
Lake [43]. As pointed out by many authors, freshwater ecosystems are commonly protected only incidentally as a result of their inclusion within terrestrial protected areas and this does not guarantee their effective protection [36, 37, 44]. Negative activities such as alteration of hydrology, land-use disturbances, high fertilization, and more can occur within NPs and LPs. Even if they take place outside of the park boundaries they can still have negative consequences for water habitats within the protected area.

In conclusion, it seems that in order to enable the implementation of the conservation tasks of parks relating to aqueous ecosystems, watersheds would have to be considered in designating their boundaries, as pointed out by Choiński [44]. The park boundaries must not be delineated only by the natural ground cover (the park boundary often ends at the forest line), but their range should include areas used by humans; therefore, related agricultural and economic restrictions should be imposed. It is also welladvised to enforce the provisions of protection programs providing for establishing buffer zones around lakes.

\section{Acknowledgements}

We would like to thank the Inspectorate for Environmental Protection for providing the data obtained within the framework of state environmental monitoring.

\section{References}

1. RAূKOWSKI G. National Parks in Poland, IEP, Warsaw, 2009 [In Polish].

2. The Act of 16 April 2004 on Nature Protection (Official Journal of the Laws No. 92, Item 880) [In Polish].

3. HILLBRICHT-ILKOWSKA A. Ecological problems of management and protection of the quality, habitats and bio- 
diversity of inland waters. [In:] L. STARKEL (Ed.). The use and protection of surface waters resources in Poland. Zeszyty Naukowe Komitetu “Człowiek i Środowisko," 17, 63, 1997 [In Polish].

4. KAJAK Z. Hydrobiology-Limnology. Ecosystems of inland waters. PWN, Warszawa, 2001 [In Polish].

5. KUFEL L. Nutrient transport in catchment areas of Mazuria Landscape Park. [In:] ZDANOWSKI B., KAMIŃSKI M., MARTYNIAK A. (Eds.). Functioning and protection of aquatic ecosystems in protected areas, IFI Publishing, Olsztyn, 153, 1999.

6. KUDELSKA D., CYDZIK D., SOSZKA H. System of lake quality evaluation, Instytut Kształtowania Środowiska, Warszawa, 1983 [In Polish].

7. BAJKIEWICZ-GRABOWSKA E. Assessment of natural susceptibility to degradation of lakes and the role of the catchment in this process. Wiad. Ekol., 33, (3), 279, 1987 [In Polish].

8. Directive 2000/60/EC of the European Parliament and of the Council of 23 October 2000 establishing a framework for Community action in the field of water policy

9. The draft Regulation of the Minister of the Environment of 8 May 2013 amending the Regulation on the manner of classifying surface water bodies and environmental quality standards for priority substances [In Polish].

10. REKOLAINEN S. Phosphorus and nitrogen load from forest and agricultural areas in Finland. Aqua Fennica 19, (2), 95, 1982.

11. BAJKIEWICZ-GRABOWSKA E. Circulation of matter in the river-lake systems. UW Publishing, Warsaw, 2002 [In Polish].

12. SMAL H., KORNIJÓW R., LIGĘZA S. The effect of catchment on water quality and eutrophication risk of five shallow lakes (Polesie region, Eastern Poland). Pol. J. Ecol., 53, (3), 313, 2005.

13. KORNAŚ M., GRZEŚKOWIAK A. The impact of the use of a catchment on water quality in water reservoirs in the Drawa River catchment. Woda-Środowisko-Obszary Wiejskie, 11, (1), 125, 2011 [In Polish].

14. CURTIS J., MORGENROTH E. Estimating the effects of land-use and catchment characteristics on water quality: Irish lakes 2004-2009. Journal of the Statistical and Social Inquiry Society of Ireland, 42, 64, 2013.

15. SZYPER H., GOŁDYN R. Role of catchment area in the transport of nutrients to lakes in the Wielkopolska National Park in Poland. Lakes and Reservoirs: Research and Management, 7, 25, 2002.

16. KUFEL I., KUFEL L. Spatial variability and long-term changes of the trophic parameters in the Great Masurian Lakes (Poland). Pol. J. Ecol., 47, (3), 323, 1999.

17. HILLBRICHT-ILKOWSKAA. Evaluation of the phosphorus load, and degree of endangerment, of lakes In Suwałki Landscape Park, and some relationship between the load and the indices of thwe trophic status of lakes. [In]: HILLBRICHTILKOWSKAA., WIŚNIEWSKI R.J. (Eds.). Lakes of Suwałki Landscape Park. Zeszyty Naukowe Komitetu Naukowego "Człowiek i Środowisko," 7, 243, 1994.

18. ZDANOWSKI B. Eutrophication of lakes in Wigry National Park: threats and their assessment. [In:] ZDANOWSKI B., KAMIŃSKI M., MARTYNIAK A. (Eds.). Functioning and protection of aquatic ecosystems in protected areas, IFI Publishing, Olsztyn, 261, 1999.

19. HILLBRICHT-ILKOWSKA A. Links between landscape, catchment basin, wetland, and lake: the Jorka river-lake system (Masurian Lakeland, Poland) as the study object. Pol. J. Ecol., 50, (4), 411, 2002.
20. HILLBRICHT-ILKOWSKA A. Nutrient loading and retention in lakes of the Jorka river system (Masurian Lakeland, Poland): seasonal and long-term variation. Pol. J. Ecol., 50, (4), 459, 2002.

21. EJSMONT-KARABIN J. An analysis based on rotifer indices of the effects of water and sewage management on water quality in the system of interconnected glacial lakes. Limnological Rev., 13, (4), 191, 2013.

22. SIUDA W., KALIŃSKI T., KAUPPINEN E., CHRÓST R. Eutrophication of the southern part of the Great Masurian Lakes complex in the years 1977 2011. Causes, mechanisms and effects. 2013 [In Polish]. Access protocol:

http://www.zemuw.pl/pl/files/docs/JM_Eutrofizacja_jezior _mazurskich.pdf

23. SZYPER H., KRASKA M. The evaluation of the external load by biogenic compounds of lakes in Drawieński National Park. [In:] Choiński A., Jańczak J. (Eds.). Anthropogenic and natural transformations of lakes. Warszawa, 255, 1999 [In Polish].

24. PYKA J. P., ZDANOWSKI B., STAWECKI K., PRUSIK S. Trends in environmental changes in the selected lakes of Mazury and Suwałki Lakelands. Limnological Rev., 7, (2), 101, 2007.

25. KUTYŁA S., PASZTALNIEC A. Developing the environmental database for lakes in Poland, Roczniki Geomatyki, 11, (5), 63, 2013 [In Polish].

26. Digital map of protected areas in Europe, EEA, Kopenhaga, 2011.

27. Digital Hydrographic Map of Poland (HMP), IMWM, Warsaw, 2005.

28. The formulation of restrictions on the use of the waters of lakes or reservoirs and on the use of their catchments in the conditions for the use of the waters of a water region [in Polish]. A study carried out on commission from the Regional Water Management Board in Cracow by the consortium MGGP S.A. and the IEP-NRI, Cracow-Warsaw, 2010 [In Polish]. Access protocol:

(http://www.rzgw.gda.pl/cms/site.files/file/RDW_2011/ RZGW_Gdansk.pdf)

29. Digital map of land cover CORINE Land Cover, CIEP, Warsaw, 2006.

30. SOSZKA H., KOLADAA., PASZTALENIEC A., OCHOCKA A., KUTYŁA S., KOPROWSKA K. An assessment of the status of lakes in 2010-2012, along with the participation in an intercalibration exercise and the development of methodology for assessing the ecological status of lakes on the basis of benthos macroinvertebrates. Stage V. Institute of Environmental Protection - National Research Institute, Warsaw, 2013 [In Polish].

31. DICKINSON J., TEEUW R. Recent land-use change in the catchment of Llangorse Lake, Brecon Beacons National Park, Wales. Aquatic Conserv: Freshw. Ecosyst., 9, 411, 1999.

32. KUCZYNSKA-KIPPEN N., JONIAK T. Chlorophyll $a$ and physical-chemical features of small water bodies as indicators of land use in the Wielkopolska region (Western Poland). Limnetica, 29, (1), 163, 2010.

33. BORS P., KOSZELNIK P. The influence of the catchment land use on the quality of surface water with the use of examples of two catchments with different levels of anthropogenic impact. Zesz. Nauk. Pol. Rzesz. Budow. i Inż. Środow. 268, (52), 17, 2009 [In Polish].

34. DAWIDEK J, PECZZUŁA W, FERENCZ B. The role of catchment and in-lake processes in shaping trophic conditions of the shallow lake Syczyńskie (Eastern Poland). Ecohydrol. Hydrobiol. 9, 193, 2009. 
35. ZDANOWSKI B., KAMIŃSKI M., MARTYNIAK A. (eds). Functioning and protection of aquatic ecosystems in protected areas, IFI Publishing, Olsztyn, 9, 1999.

36. SAUNDERS D. L., MEEUWIG J. J., VINCENT A. C. J. Freshwater protected areas: Strategies for conservation, Conservation Biology, 16, 30, 2002.

37. ABELL R., ALLAN J. D., LEHNER B. Unlocking the potential of protected areas for freshwaters. Biological Conservation, 134, 48, 2007.

38. KLIMASZYK P. Can cormorants pose a threat for the ecosystem of Lake Góreckie? [In:] WALNA B., KACZMAREK L., LORENC M., DONDAJEWSKA R. (Eds.) The National Park of Wielkopolska in Nature Research, Poznań-Jeziory, 69, 2009 [In Polish].

39. GÓRNIAK A., PIEKARSKI K. Seasonal and Multiannual Changes of Water Levels in Lakes of Northeastern Poland. Pol. J. Environ. Stud., 11, (4), 349, 2002.
40. ŁAWNICZAK A.E., CHOIŃSKI A., KURZYCA I. Dynamics of lake morphometry and bathymetry in various hydrological conditions. Pol. J. Environ. Stud., 20, (4), 931, 2011.

41. SOSZKA H., PASZTALENIEC A., KOPROWSKA K., KOLADAA., OCHOCKAA. The effect of Lake hydromorphological alterations on aquatic biota - an overview. Ochrona Srodowiska i Zasobów Naturalnych, 52, 24, 2012 [In Polish].

42. SKWIERAWSKI A., SOBCZYŃSKA-WÓJCIK K, RAFAŁOWSKA M. Phosphorus runoff from small agricultural catchments under different land use intensity. J. Elementol. 13, (4), 637, 2008.

43. PINDNER J. R. Lakes, landscapes and locals: Pooling partnership resources to create sustainable lake catchments. Lakes and Reservoirs: Research and Management, 18, 15, 2013.

44. CHOIŃSKI A. Physical limnology of Poland, UAM Science Publishing, Poznań, pp 436-485, 2007 [In Polish]. 